\title{
HUBUNGAN KARAKTERISTIK PEKERJA DENGAN UNSAFE ACTION PADA TENAGA KERJA BONGKAR MUAT DI PT. TERMINAL PETIKEMAS SURABAYA
}

\author{
Aditya Kurnia Pratama \\ Health Safety Environment (HSE) PT. Petikemas Surabaya \\ E-mail: Joyboydream@gmail.com
}

\begin{abstract}
Unsafe action is a trigger for work accident. Unsafe action happened for two reasons, such as unintentional mistakes and active errors or violation of a rule. Unsafe action influenced by the internal factor from workers itself, such as characteristic of workers. The objectivs of this research is to aims of this study are analyze the relationship between the characteristics of workers to unsafe action, in stevedor at PT. Terminal Petikemas Surabaya. This study was observational Descriptive. The sample was all stavedore in a group of which consisted of 60 people. The data presented in the form of distribution the frequency and tabulation cross then analyzed statistically the Spearman. The result of this study shown that there was an relatively low association between the characteristic of workers with unsafe action, but there was one variable had the strong enough relationship, such as knowledge variable and unsafe action on stevedore in PT. Terminal Petikemas Surabaya with coefficient corelation 0.417. Based on the result of this study, suggestions that can be given to the HSE departement are scheduled refreshment through training and briefing to increase knowledge of occupational safety and health at work, meanwhile supervisor of field have to do a strict and firmly supervise to stevedore who performing unsafe action. So it expected to reduce the number of work accident in the process of loading and unloading.
\end{abstract}

Keywords: Stevedore, unsafe action, characteristic of workers

\begin{abstract}
ABSTRAK
Unsafe action adalah tindakan yang memicu terjadinya suatu kecelakaan kerja. Unsafe action terjadi karena dua hal, yaitu karena kesalahan yang tidak disengaja dan kesalahan aktif atau pelanggaran. Tindakan tidak aman dipengaruhi oleh faktor internal dari pekerja itu sendiri, diantaranya adalah karakteristik pekerja. Penelitian ini bertujuan untuk menganalisis hubungan antara karakteristik pekerja terhadap unsafe action, pada Tenaga Kerja Bongkar Muat di PT. Terminal Petikemas Surabaya. Penelitian ini bersifat observasional diskriptif. Sampel penelitian merupakan semua Tenaga Kerja Bongkar Muat dalam satu Kelompok yang berjumlah 60 orang. Data yang disajikan dalam bentuk distribusi frekuensi dan tabulasi silang kemudian dianalisis secara statistik Spearman. Hasil penelitian menunjukkan bahwa ada hubungan yang relatif rendah antara karakteristik pekerja dengan unsafe action, namun ada satu variabel yang memiliki hubungan cukup kuat, yaitu variabel pengetahuan dan unsafe action pada Tenaga Kerja Bongkar Muat di PT. Terminal Petikemas Surabaya dengan koefisien koerelasi sebesar 0,417. Berdasarkan hasil penelitian ini saran yang dapat diberikan adalah departemen HSE memberikan penyegaran melalui pelatihan maupun pengarahan yang terjadwal untuk meningkatkan pengetahuan K3 di tempat kerja, selain itu Supervisor lapangan juga harus melakukan pengawasan yang ketat dan lebih tegas kepada Tenaga Kerja Bongkar Muat yang melakukan unsafe action, sehingga diharapkan dapat menekan angka kecelakaan kerja pada proses bongkar muat.
\end{abstract}

Kata kunci: Tenaga Kerja Bongkar Muat, unsafe action, karakteristik pekerja

\section{PENDAHULUAN}

Pada awal abad Ke 21 angka kecelakaan kerja di dunia dalam kondisi yang cukup mengkhawatirkan. Menurut International Labour Organization (ILO) setiap tahun dua juta orang meninggal dan 270 juta orang cidera akibat kecelakaan kerja yang terjadi di seluruh dunia. Perkembangan kecelakaan kerja di negara berkembang juga sangat tinggi, termasuk Indonesia, hal ini disebabkan karena negara berkembang banyak industri padat karya, sehingga lebih banyak pekerja yang terpapar oleh potensi bahaya (ILO, 2013). Berdasarkan data dari Kementerian Tenaga Kerja dan Transmigrasi menyebutkan bahwa pada tahun 2009 terjadi kecelakaan kerja sebanyak 54.398 kasus (Permana, 2014).

Menurut Undang-Undang No.1 Tahun 1970 Tentang Keselamatan Kerja, dikatakan bahwa setiap tenaga kerja berhak mendapat perlindungan atau keselamatan dalam melakukan pekerjaan di tempat 
kerja perlu terjamin keselamatannya, sehingga kewajiban dalam menerapkan K3 dalam sebuah instansi ataupun perusahaan hukumnya wajib. Dewan Keselamatan Kerja dan Kesehatan Kerja nasional (DK3N) mengatakan kecelakaan kerja dapat menyebabkan terjadinya kerugian langsung (direct lost) dan kerugian tidak langsung (indirect lost). Kerugian langsung misalnya, jika terjadi kecelakaan maka perusahaan akan mengalami kerugian karena harus mengeluarkan biaya pengobatan dan biaya perbaikan kerusakan sarana produksi. Kerugian tidak langsung berupa kerugian jam kerja hilang, kerugian produksi, kerugian sosial dan menurunnya citra perusahaan serta kepercayaan konsumen (Septiana, 2014).

Menurut H.W. Heinrich dalam terjadinya kecelakaan kerja dipengaruhi oleh 2 (dua) penyebab langsung yaitu unsafe action (tindakan tidak aman) dan unsafe condition (kondisi tidak aman). Tindakan tidak aman adalah suatu tindakan yang tidak memenuhi keselamatan sehingga berisiko menyebabkan kecelakaan kerja (Ramli, 2010). Kondisi tidak aman adalah keadaan lingkungan yang tidak aman dan berisiko menyebabkan kecelakaan kerja (Gatiputri, 2011). Studi yang dilakukan Heinrich tahun 1928 pada 75 ribu kasus kecelakaan industri didapatkan $88 \%$ disebabkan oleh tindakan tidak aman, $10 \%$ oleh kondisi tidak aman dan $2 \%$ tidak dapat dihindarkan seperti bencana alam (Ramli, 2010). Hal ini dapat disimpulkan bahwa setiap pekerjaan pasti mempunyai risiko terjadi kecelakaan, karena lingkungan pekerjaan tidak pernah terlepas dari faktor individu yaitu pekerja dan kondisi tidak aman dalam lingkungan kerja.

Seiring dengan kebutuhan manusia yang semakin banyak dan beragam, hal ini membuat aktivitas perpindahan barang yang semakin tinggi, terutama aktivitas transportasi laut yang semakin meningkat membuat penyediaan layanan di bidang terminal petikemas di sebuah pelabuhan meningkat, Hal ini berpotensi meningkatkan jumlah kecelakaan kerja. Menurut data di Indonesia, pada tahun 2007 terjadi 89.000 kecelakaan kerja di seluruh perusahaan yang menjadi anggota Jamsostek yaitu meliputi 7 juta pekerja, Jika jumlah pekerja di Indonesia mencapai lebih dari 90 juta orang maka jumlah kecelakaan diperkirakan lebih dari 700.000 kejadian setiap tahun. ILO memperkirakan kerugian akibat kecelakaan mencapai 2-4\% dari GNP suatu negara (Ramli, 2010).

Beberapa penelitian yang telah dilakukan menunjukkan bahwa faktor manusia menempati posisi yang sangat penting terhadap terjadinya kecelakaan kerja yaitu 80 sampai $85 \%$ (Suma'mur 2009). Unsafe action adalah faktor yang berhubungan dengan perilaku manusia dalam melakukan pekerjaan di industri. Berdasarkan penelitian yang dilakukan oleh Daniel M. Rosyid (2011) di Pelabuhan Tanjung Perak Surabaya mengenai peran manusia dalam tubrukan kapal dengan menggunakan metode Analysis Hierarchial Proccess (AHP) dan data disajikan dalam bentuk Fault Tree yang menjelaskan tentang penyebabpenyebab kegagalan manusia dalam melakukan pekerjaan. Hasil penelitian tersebut menunjukkan bahwa sebagian besar kesalahan yang dilakukan sehingga menyebabkan tubrukan kapal disebabkan oleh faktor manusia yang melakukan pekerjaan tidak sesuai dengan prosedur (Rosyid, 2011). Berdasarkan uraian di atas dapat disimpulkan bahwa kecelakaan disebabkan oleh tindakan tidak aman (unsafe action).

Unsafe action dalam suatu proses pekerjaan dapat ditekan dengan pembentukan program K3 oleh perusahaan. Program K3 dapat membentuk Perilaku aman pada pekerja. Perilaku aman dipengaruhi oleh faktor individu dan lingkungan kerja. Perilaku aman mencegah terjadinya kecelakaan kerja. Perilaku aman juga mampu menunjukkan nilai, keyakinan dan sikap terhadap keselamatan pekerja (Suma'mur, 2009).

Kecelakaan kerja membawa akibat yang merugikan bagi pengusaha, tenaga kerja, pemerintah dan masyarakat, antara lain adalah korban jiwa manusia, hilang atau berkurangnya kesempatan kerja, tenaga terampil, modal yang tertanam dan lain-lain. Karena itu dalam setiap usaha perluasan kesempatan kerja, masalah keselamatan dan kesehatan kerja perlu mendapat perhatian sepenuhnya (Silalahi, 1995). Kecelakaan kerja dalam sebuah instansi ataupun perusahaan sangat perlu dilakukan untuk menghindari dampak buruk yang ditimbulkan.

Dalam buku berjudul Kamus Manajemen Mutu menyatakan kecelakaan kerja sebagai teori gunung es (Iceberg Theory). Teori gunung es menjelaskan bahwa kerugian pada kecelakaan kerja yang tampak, terlihat lebih kecil dari pada kerugian keseluruhannya. Dalam hal ini kerugian yang "tampak" ialah terkait dengan biaya langsung untuk penanganan/perawatan/pengobatan korban kecelakaan kerja tanpa memperhatikan kerugiankerugian lainnya yang bisa jadi berlipat-lipat jumlahnya dari pada biaya langsung untuk korban kecelakaan kerja (Sugian, 2006). 
Menurut Silalahi (1995) terdapat empat faktor bergerak dalam satu kesatuan berantai yang dapat menyebabkan kecelakaan kerja, yaitu: lingkungan, peralatan, bahaya dan manusia, ternyata kecelakaan kerja bukan hanya dipengaruhi oleh faktor lingkungan fisik saja, melainkan salah satu faktor yang paling penting adalah manusia. Hal ini karena manusia lah yang berperan sebagai subjek pelaku kerja, sehingga faktor penyebab kecelakaan kerja tidak bisa dilepaskan dari karakteristik dan perilaku manusia (Santoso, 2004).

Dalam beberapa dekade terakhir, banyak peneliti yang telah mengembangkan teori dan metode spesifik untuk menyelidiki aspek psikososial performa keselamatan dalam organisasi dan dilakukan berbagai penelitian terhadap keselamatan kerja, salah satunya pada tingkatan individual yakni sikap terhadap keselamatan kerja. (Chyene et al (2002), menemukan bahwa sikap terhadap keselamatan kerja memiliki hubungan yang positif dan signifikan terhadap aktivitas keselamatan kerja. Sehingga ketika seseorang memiliki sikap terhadap keselamatan kerja yang tinggi maka ia akan berusaha untuk selalu menggunakan alat pelindung diri dan mematuhi peraturan keselamatan kerja di lingkungan kerjanya.

Karakteristik pekerja memiliki peranan dalam landasan seseorang mengambil keputusan dan berperilaku, salah satunya adalah melakukan tindakan tidak aman dalam melakukan pekerjaan. Tindakan tidak aman dari pekerja sangat krusial dalam menentukan keselamatan di lingkup kerja.

Penelitian ini bertujuan untuk menganalisis hubungan antara karakteristik pekerja dengan unsafe action pada Tenaga Kerja Bongkar Muat di PT. Terminal Petikemas Surabaya.

\section{Identifikasi Masalah}

Pada uraian di atas dijelaskan bahwa aktivitas di Pelabuhan Tanjung Perak semakin meningkat, hal tersebut berpotensi meningkatnya frekuensi terjadi kecelakaan di Terminal Petikemas, selain itu Terminal Petikemas memiliki tingkat keparahan yang tinggi jika terjadi kecelakaan kerja, oleh karena itu penulis memilih PT Terminal Petikemas Surabaya sebagai tempat penelitian. PT Petikemas Surabaya adalah perusahaan yang menyediakan jasa pemuatan, pembongkaran, penerimaan dan pengeluaran petikemas, dalam perusahaan ini masih didominasi manusia sebagai pekerja, sehingga penulis ingin mengetahui pengaruh dari unsafe action pada pekerja di PT Terminal Petikemas Surabaya terhadap terjadinya kecelakaan kerja.

Besarnya kerugian yang disebabkan oleh kecelakaan kerja membuat sebuah perusahaan harus berupaya mencegah bahkan menghapuskan angka kecelakaan kerja. Sebuah perusahaan melakukan upaya untuk menekan terjadinya kecelakaan dengan cara mengendalikan faktor-faktor yang menjadi penyebab kecelakaan kerja, namun dibalik semua upaya tersebut tidak ada artinya jika kesadaran tentang keselamatan kerja tidak dimiliki oleh pekerja. Upaya pereduksi hazard di area kerja sangat dipengaruhi oleh individu itu sendiri, apakah patuh atau tidak, sehingga dalam memilih kebijakankebijakan dalam upaya keselamatan dan kesehatan kerja oleh pihak keselamatan dan kesehatan kerja, harus diikuti dengan pertimbangan dan pemahaman bagaimana karakteristik pekerjaannya. Perusahaan harus mengetahui karakteristik individu seperti apa yang memiliki potensi melakukan tindakan tidak aman lebih besar. Sehingga dalam kesempatan kali ini penulis ingin mengobservasi apakah ada hubungan antara karakteristik dengan perilaku tidak aman (unsafe action) pada tenaga kerja bongkar muat di proses loading dan unloading PT Terminal Petikemas Surabaya.

\section{METODE}

Penelitian ini bersifat deskriptif karena penulis ingin di ketahui hubungan antara karakteristik pekerja dan terhadap perilaku tidak aman (unsafe action). Dari waktu pengumpulan data merupakan penelitian yang menggunakan pendekatan observasional yang bersifat cross sectional dengan metode pengumpulan data primer dan sekunder.

Penelitian ini juga bersifat kuantitatif, karena penelitian ini mengambil data dengan memberi bobot atau skor dalam butir pertanyaan yang ada di dalam kuesioner, dan menggunakan kuesioner sebagai alat pengumpulan data.

Populasi dalam penelitian ini adalah seluruh pekerja dalam satu kelompok Tenaga Kerja Bongkar Muat (TKBM) yang melakukan proses Loading dan Unloading di PT. Terminal Petikemas Surabaya. Penelitian ini, sampel dipilih dari populasi studi yang memenuhi kriteria inklusi.

Dalam pemilihan sampel peneliti menetapkan kriteria sampel yaitu, Tenaga Kerja Bongkar Muat dalam satu kelompok shift. Tenaga kerja bongkar muat yang masuk dalam kategori unsafe action, rendah, cukup, sedang dan tinggi. Tenaga kerja 
bongkar muat yang melakukan pekerjaan proses bongkar muat di PT. Terminal Petikemas Surabaya.

Penelitian ini akan dilaksanakan di PT Terminal Petikemas surabaya yang berada di jalan Jl. Tanjung Mutiara 1 Surabaya 60177 , Jawa Timur. Waktu pengambilan data dilaksanakan pada bulan Juni 2015 sampai dengan bulan Juli 2015.

Data yang dikumpulkan pada penelitian ini meliputi: data primer yaitu data yang diperoleh dari pengamatan dan pengisian kuesioner di lapangan, meliputi Wawancara untuk mengetahui karakteristik pekerja, Observasi yang bertujuan untuk melihat kondisi tidak aman yang dilakukan oleh pekerja.

Data sekunder merupakan data yang diperoleh dari pihak perusahaan khususnya bagian keselamatan kerja PT Terminal Petikemas Surabaya, seperti buku, dokumen perusahaan, dan peraturan atau kebijakan perusahaan, pencatatan dan pelaporan lain yang mendukung penelitian ini.

Prosedur dari penelitian ini meliputi, memilih sampel berdasarkan kriteria inklusi yang telah ditetapkan. Dari Seluruh sampel yang telah dipilih, dilakukan wawancara mengenai karakteristik pekerja dan dilakukan observasi mengenai unsafe action pada saat proses bongkar muat, setelah data sudah terkumpul, dilakukan analisis data.

Teknik analisis data dalam penelitian ini dilakukan dengan menggunakan tabulasi silang. Setelah itu untuk melihat hubungan antar variable digunakan uji korelasi Spearman, hal ini dikarenakan skala data semua adalah ordinal. Cara pengolahan data menggunakan aplikasi SPSS.

Mengetahui tingkat hubungan antar variable akan dihitung dengan koefisien korelasi yang dilambangkan $(r)$. Ketentuan nilai $r$ mempunyai rentang nilai -1 sampai dengan 1, di mana nilai $r=-1$ adalah korelasi negative sempurna atau korelasi terbalik, nilai $r=0$ adalah tidak ada korelasi dan nilai $r=1$ adalah korelasi sempurna (sangat kuat). Interpretasi nilai $r$ ditampilkan dalam Table 1 berikut ini:

Tabel 1. Interpretasi Koefisien Korelasi Nilai $r$

\begin{tabular}{cl}
\hline Interval Koefisien & Tingkat Hubungan \\
\hline $0,00-0,199$ & Sangat Rendah \\
$0,20-0,399$ & Rendah \\
$0,40-0,599$ & Cukup Kuat \\
$0,60-0,799$ & Kuat \\
$0,80-1,000$ & Sangat Kuat \\
\hline
\end{tabular}

Sumber: Riduwan, 2013

Setelah data di analisis, langkah selanjutnya adalah melakukan penarikan kesimpulan.

\section{HASIL}

\section{Gambaran umum Tempat penelitian}

Terminal Petikemas Internasional di Surabaya pertama kali beroperasi dalam tahun 1992. Fasilitas ini kemudian diprivatisasi di bulan April 1999 menjadi PT. Terminal Petikemas Surabaya, dan tak lama kemudian pihak investor asing diundang dan membeli saham perusahaan. Pada tanggal 1 Mei 2006, PT. Pelabuhan Indonesia III (Persero) dan Anak Perusahaannya memiliki 51\% saham dan DP World (dahulu P\&O Ports Australia) memiliki $49 \%$ saham. TPS dalam tahun-tahun pengoperasiannya telah memiliki reputasi sebagai sebuah Terminal Petikemas yang efisien dan efektif terhadap biaya yang mampu melayani kebutuhan masyarakat pelayaran dan para importir dan eksportir di Indonesia Bagian Timur.

Fasilitas dermaga sepanjang 1,450 meter dan Lapangan Penumpukan Petikemas seluas 40 hektar berkapasitas untuk menangani lebih dari dua juta terus per tahun. Dalam tahun 2004, untuk pertama kalinya TPS mampu menangani lebih dari satu juta terus dalam tahun kalender. Setiap fungsi operasional dan bisnis difasilitasi dengan komputer. Sistem Operasional Terminal, yaitu TOPS, dipasok oleh Realtime Business Solutions dari Sydney, Australia. TPS, lewat eTPS memberikan layanan kepada para kliennya, yaitu berupa sistem pengontrolan dan perencanaan penanganan petikemas. TPS memperoleh sertifikatsertifikat antara lain: ISO 9001 (Standar Mutu), ISO 14001 (Standar Lingkungan), OHSAS 18000 (Standar Kesehatan dan Keselamatan Kerja), yang menunjukkan komitmen Perusahaan terhadap efisiensi dan produktivitas, menciptakan tempat kerja yang aman bagi seluruh pegawai dan tamu ke Terminal, serta meminimalkan dampak-dampak dari pengoperasian Terminal yang mungkin terjadi terhadap lingkungan sekitarnya.

Di bulan Mei 2008, TPS telah menjadi satusatunya Terminal Petikemas di Indonesia dan di dunia, yang telah memperoleh sertifikast C-TPAT (Bea Cukai - Partner Dagang terhadap Terorisme). Alhasil, petikemas yang diekspor ke Amerika Serikat tidak perlu lagi menjalani pemeriksaan Bea Cukai. Produktivitas terminal dipantau secara terusmenerus. Dalam lima tahun terakhir ini, tingkat penanganan kapal petikemas telah meningkat dua kali lipat, dan waktu balik truk (TRT) telah menurun sampai $50 \%$. 
Komponen-komponen yang sekaligus merupakan fasilitas sebuah terminal petikemas dalam menunjang kelancaran penanganan petikemas termasuk bongkar muat di dalam suatu terminal petikemas yaitu Sarana, untuk melaksanakan kegiatan bongkar muat petikemas, maka Terminal Petikemas harus dilengkapi dengan berbagai fasilitas (Salim, 1994) seperti Berth (Dermaga), tempat bersandarnya kapal dan biasanya mempunyai panjang dan kedalaman tertentu disesuaikan dengan jenis kapal yang berlabuh. Marshaling yard, tempat untuk menyusun barang yang siap bongkar dan muat dari kapal. Lapangan ini terletak di dekat apron. Container yard, lapangan yang digunakan untuk menangani/ menyimpan petikemas yang mengendap. Container freight service (CFS), tempat yang ditunjuk pengirim barang untuk menyusun dan membongkar barangnya dari petikemas. Maintenance and repair shop, tempat untuk memperbaiki dan perawatan petikemas, Control tower, tempat untuk mengawasi kegiatan di Marshaling Yard dan Container Yard, Ship planning centre, pusat perencanaan muatan dan pembongkaran container dari dan ke dalam kapal. Weighting bridge, jembatan timbang untuk menghitung berat petikemas yang akan dimuat dan dibongkar dari kapal.

Prasarana, untuk menunjang kegiatan bongkar muat petikemas, maka terminal petikemas harus dilengkapi dengan alat-alat bongkar muat (Subandi, 1993) :Straddle carrier, biasa disebut Straddle Truck yaitu alat bongkar muat mekanis di dermaga untuk menangani petikemas. Alat ini digunakan mengangkat muatan yang berukuran panjang (long length) seperti kayu-kayu. Forklift, terdapat 2 jenis yaitu Forklift besar digunakan untuk mengangkat petikemas dari lambung kapal ke chassis/trailer, forklift kecil digunakan untuk menyusun muatan/ membongkar petikemas (stuffing/stripping), dan Shore crane, biasa disebut Quayside Crane, Portainer, Transtainer atau juga Shore Gantry Spreader. Alat untuk memuat barang dari dermaga ke kapal dan sebaliknya. Alat ini dapat berjalan di sepanjang dermaga karena berdiri di atas kaki yang beroda, di atas rel atau dengan ban.

\section{Distribusi tenaga kerja}

Pada Tabel 2 distribusi tenaga kerja dibagi menjadi 2 area lokasi kerja yaitu dermaga dan lapangan. Jumlah pekerja yang bekerja di TPS tidak seluruhnya pekerja TPS akan tetapi TPS bekerja sama dengan mitra kerja. TPS mempunyai
Tabel 2. Distribusi Tenaga Kerja Shift di PT. Terminal Petikemas Surabaya

\begin{tabular}{lrr}
\hline Pekerjaan & (n) & \multicolumn{1}{c}{$(\mathbf{\% )}$} \\
\hline Security & 119 & 10.17 \\
Safety Supervisor & 8 & 0.68 \\
HT Operators & 304 & 25.98 \\
QC Maintenance & 83 & 7.09 \\
RTG Maintenance & 58 & 4.95 \\
RS/SL Maintenance & 16 & 1.36 \\
HT Maintenance & 68 & 5.81 \\
RS/SL Operator & 21 & 1.79 \\
Drivers - Shuttle Bus \& Operation Cars & 17 & 1.45 \\
Stevedore (Lashers) & 248 & 21.19 \\
Tallyman & 102 & 8.71 \\
Assistant to Yard Supervisor & 21 & 1.79 \\
Cargo Control & 4 & 0.34 \\
Stock Opname & 47 & 4.01 \\
Gate Operator & 47 & 4.01 \\
Gear Store & 4 & 0.34 \\
IT Help Desk & 9 & 0.76 \\
RTG Operator & 35 & 2.99 \\
CC Operator & 18 & 1.53 \\
\hline Total & $\mathbf{1 1 7 0}$ & $\mathbf{1 0 0 \%}$ \\
\hline
\end{tabular}

kebijakan kesehatan, keselamatan dan lingkungan sebagai upaya pemenuhan peraturan perundangan yang berlaku dan perlindungan terhadap tenaga kerja, masyarakat dan lingkungan. Sebagai upaya pemenuhan terhadap kebijakan manajemen, HSSE Department memiliki tahapan sebagai berikut:

Melakukan identifikasi bahaya dan pengukuran risiko di setiap area kerja TPS.

Sebelum melaksanakan pekerjaan, para kontraktor wajib memenuhi ketentuan LK4 (Lingkungan, Kesehatan dan Keselamatan Kerja). Dan Menetapkan standar masuk kepada seluruh orang yang memasuki daerah lini I TPS yaitu safety shoes, safety helmet, dan safety vest.

Untuk penanganan pencemaran lingkungan, TPS memiliki mesin OWS (Oil Water Separator), mesin pembakaran (incinerator), tempat penanganan tumpahan bahan kimia, tempat penimbunan sampah bahan beracun dan berbahaya (B3). TPS juga melakukan pengukuran kualitas udara ambient, kualitas emisi gas buang tidak bergerak dari incinerator, kualitas emisi gas buang bergerak (Head Truck, Forklift, RTG, CC, dan kendaraan operasional), temperatur, kebisingan, air limbah hasil olahan OWS dan air laut. Sebagai penunjang kesehatan, TPS mempunyai klinik 24 jam yang berada di area dermaga dan di kantor gedung baru. Klinik ini didirikan sebagai antisipasi 
dan penanganan terjadinya kecelakaan kerja dan pemeriksaan kesehatan berkala terhadap seluruh tenaga kerja TPS.

Terdapat 3 faktor yang dapat menjadi penyebab terjadinya kecelakaan kerja di area dermaga dan lapangan, di mana 3 faktor tersebut dapat menyebabkan tingkat keparahan kecelakaan kerja yaitu faktor manusia, kecerobohan dalam menjalankan kapal, kekurangmampuan awak kapal dalam menguasai berbagai permasalahan yang mungkin timbul dalam operasional kapal dan secara sadar memuat kapal secara berlebihan. Faktor teknis biasanya terkait dengan kekurangcermatan desain kapal, penelantaran perawatan kapal sehingga mengakibatkan kerusakan kapal atau bagianbagian kapal yang menyebabkan kapal mengalami kecelakaan, terbakarnya kapal seperti yang dialami Kapal Tampomas diperairan Masalembo, Kapal Livina. Yang terakhir adalah faktor alam, Faktur cuaca buruk merupakan permasalahan yang seringkali dianggap sebagai penyebab utama dalam kecelakaan laut. Permasalahan yang biasanya dialami adalah badai, gelombang yang tinggi yang dipengaruhi oleh musim/badai, arus yang besar, kabut yang mengakibatkan jarak pandang yang terbatas.

\section{Distribusi karakteristik pekerja dan unsafe action}

Tabel 3. Distribusi Karakteristik Pekerja dan Unsafe Action

\begin{tabular}{llrr}
\hline \multicolumn{1}{c}{ Variabel } & \multicolumn{1}{c}{ Kategori } & N & \% \\
\hline Umur & Remaja & 5 & 8.3 \\
& Dewasa & 23 & 38,3 \\
& Lansia & 32 & 53 \\
Masa Kerja & 1-6 Tahun & 14 & 23,3 \\
& 7-13 Tahun & 18 & 30,3 \\
& 14-20 Tahun & 16 & 27,1 \\
& 21-28 Tahun & 11 & 18,6 \\
Pendidikan & SD & 2 & 3,3 \\
Terakhir & SMP & 7 & 11,7 \\
& SMA & 46 & 76,7 \\
Pengetahuan & Diploma/Sarjana & 5 & 8,3 \\
& Kurang & 8 & 13,3 \\
& Cukup & 20 & 33,3 \\
Unsafe Action & Baik & 32 & 53,3 \\
& Rendah & 18 & 30 \\
& Cukup & 27 & 45 \\
& Sedang & 15 & 20 \\
& Tinggi & 0 & 0 \\
\hline
\end{tabular}

Berdasarkan Tabel 3 pada kolom umur Kriteria usia pada tenaga kerja dikategorikan menjadi 3 yaitu remaja, dewasa dan lansia. Remaja dikategorikan mulai usia 17 sampai dengan 25 tahun. Usia dewasa dimulai pada usia 26 sampai 45 tahun dan usia lansia di atas 45 tahun. Berikut adalah frekuensi usia responden Tenaga Kerja Bongkar Muat PT. TPS

Berdasarkan tabel di atas diketahui bahwa responden yang memiliki usia remaja rentang 17 sampai 25 tahun adalah sebanyak 5 responden dengan persentase $(8,3 \%)$. Usia 26 sampai 45 tahun atau kategori usia dewasa sebanyak $(38,3 \%)$ dari total 23 responden atau sebanyak 11 orang, sedangkan 32 responden lainnya dengan persentase $(53 \%)$, merupakan kategori usia lansia rentang di atas 45 tahun.

Pada kolom Masa kerja tenaga kerja dikategorikan menjadi 4 yaitu masa kerja 1 sampai 6 tahun, masa kerja 7 sampai 13 tahun, masa kerja 14 sampai 20 tahun., dan 21 sampai 28 tahun Berikut adalah frekuensi masa kerja responden yang didapatkan dari hasil kuesioner.

Berdasarkan Tabel di atas Sebesar 14 tenaga kerja dari total responden memiliki masa kerja 1-6 Tahun dengan total persentase $(23,3 \%)$. Frekuensi masa kerja 7 sampai 13 tahun didapatkan sebanyak 18 responden atau $(30,5 \%)$ pada masa kerja 14 20 tahun terdapat 16 responden atau $(27,1 \%)$ dan $(18,6 \%)$ atau sebanyak 11 tenaga kerja dengan masa kerja 21-28 Tahun.

Pada kolom pendidikan terakhir di tabel 4, Kriteria pendidikan terakhir pada tenaga kerja dikategorikan menjadi 4 yaitu SD, SMP, SMA, Diploma/Sarjana.. Berikut adalah frekuensi tingkat pendidikan responden Tenaga Kerja Bongkar Muat PT. TPS.

Berdasarkan Tabel di atas Distribusi tingkat pendidikan terakhir pada tenaga kerja bongkar muat adalah 2 pekerja atau $(3,3 \%)$ dengan tingkat pendidikan SD, 7 responden dengan tingkat pendidikan terakhir SMP , 46 atau sebesar $(76,6 \%)$ dengan Tingkat pendidikan SMA dan (8,3\%) dengan tingkat pendidikan Diploma/Sarjana.

Pada tabel 3 di kolom Pengetahuan yang dimaksud adalah pengetahuan tentang $\mathrm{K} 3$, dalam penelitian ini pengetahuan dikategorikan menjadi 3 yaitu Kurang, Cukup dan Baik. Berikut adalah frekuensi masa kerja responden yang didapatkan dari hasil kuesioner.

Berdasarkan tabel di atas Hasil kuesioner responden dengan pengetahuan Kurang adalah 
sebanyak 8 responden dengan persentase $(13,3 \%)$. Kategori cukup sebanyak $(33,3 \%)$ dari total responden atau sebanyak 20 orang, sedangkan 32 responden lainnya dengan persentase (53\%), merupakan kategori baik.

Sedangkan, pada kolom terakhir yaitu unsafe action dapat diketahui Dalam penelitian ini membagi Unsafe Action menjadi 4 kategori, yaitu Rendah jika index Unsafe actionnya sebesar $<25 \%$, cukup jika index unsafe Actionnya sebesar 26-50\%, sedang jika index unsafe actionnya sebesar $51-75 \%$ dan tinggi jika index unsafe action sebesar $>76 \%$. Berikut distribusi Unsafe action

Berdasarkan Tabel distribusi Unsafe action adalah 27 responden atau sebesar $(45,0 \%)$ Tenaga Kerja Bongkar Muat dinyatakan unsafe action berkategori Rendah, dan tidak ada satu pun responden memiliki unsafe action kategori tinggi.

\section{PEMBAHASAN}

\section{Umur}

Umur adalah rentang usia responden sejak lahir hingga penelitian dilakukan. Dalam penelitian ini umur responden dikelompokkan menjadi 3 kelompok umur, yaitu remaja dengan kategori umur 17 sampai dengan 25 tahun, usia dewasa dengan kategori umur 26 sampai 45 tahun dan usia lansia di atas 45 tahun. Jumlah responden dalam penelitian ini adalah 60 Tenaga Kerja Bongkar Muat di PT. Terminal Petikemas Surabaya. Sebanyak 5 responden $(8,3 \%)$ termasuk dalam kategori umur remaja, sebanyak 23 responden $(38,3 \%)$ masuk dalam kategori dewasa, dan sisanya sebanyak 32 responden (53\%) berada di kelompok umur Lansia. Tenaga Kerja Bongkar Muat PT. Terminal Peti Kemas Surabaya, banyak berada di kategori umur Dewasa dan Lansia karena perusahaan memberikan upah kerja yang sangat layak untuk Tenaga Kerja Bongkar Muat, selain itu perusahaan juga memberikan bonus pada Tenaga Kerja Bongkar Muat untuk pencapaian kerjanya. Kebijakan perusahaan tersebut menumbuhkan loyalitas para Pekerja terhadap perusahaan, karena dengan layaknya upah kerja yang diberikan, banyak dari para pekerja memilih untuk tetap bekerja menjadi Tenaga Kerja Bongkar Muat di PT. TPS.

\section{Masa Kerja}

Masa kerja adalah lamanya responden bekerja yang dihitung dari awal masuk kerja sampai penelitian ini dilakukan, pada penelitian ini masa kerja dikategorikan menjadi 4 yaitu masa kerja 1 sampai 6 tahun, masa kerja 7 sampai 13 tahun, masa kerja 14 sampai 20 tahun., dan 21 sampai 28 tahun. Dalam penelitian yang melibatkan 60 responden didapatkan bahwa Sebesar 14 tenaga kerja dari total responden memiliki masa kerja 1-6 Tahun dengan total persentase $(23,3 \%)$. Frekuensi masa kerja 7 sampai 13 tahun didapatkan sebanyak 18 responden atau $(30,5 \%)$ pada masa kerja $14-20$ tahun terdapat 16 responden atau $(27,1 \%)$ dan $(18,6 \%)$ atau sebanyak 11 tenaga kerja dengan masa kerja 21-28 Tahun. Berdasarkan Hasil dari penelitian ini terdapat 46 responden yang bekerja sebagai TKBM lebih dari 7 tahun. Banyak dari TKBM memiliki masa kerja yang cukup lama, hal ini menunjukkan bahwa di PT. Terminal Petikemas Surabaya memiliki lingkungan kerja yang nyaman.

\section{Pendidikan Terakhir}

Pendidikan Terakhir dapat diartikan tingkatan pendidikan terakhir responden yang ditamatkan sebelum penelitian dilakukan. Tingkat pendidikan dalam penelitian ini dikelompokkan menjadi SD, SMP, SMA, Diploma/Sarjana. Jumlah responden adalah 60 responden, Distribusi tingkat pendidikan terakhir pada Tenaga Kerja Bongkar Muat adalah 2 pekerja atau $(3,3 \%)$ dengan tingkat pendidikan SD, $7(11,7 \%)$ responden dengan tingkat pendidikan terakhir SMP, 46 atau sebesar (76,6\%) dengan Tingkat pendidikan SMA dan 8,3\% dengan tingkat pendidikan Diploma/Sarjana. Tenaga Kerja Bongkar Muat merupakan pekerjaan yang lebih membutuhkan keterampilan, fisik dan skill dibandingkan dengan kemampuan pendidikan formal.

\section{Pengetahuan}

Pengetahuan yang dimaksud adalah pengetahuan tentang Keselamatan kesehatan kerja dalam proses bongkar muat, dalam penelitian ini, pengetahuan dikategorikan menjadi 3 yaitu Kurang, Cukup dan Baik. Berdasarkan hasil penelitian melalui kuesioner, responden dengan pengetahuan Kurang adalah sebanyak 8 responden dengan persentase $(13,3 \%)$. Kategori cukup sebanyak $(33,3 \%)$ dari total responden atau sebanyak 20 orang, sedangkan 32 responden lainnya dengan persentase (53\%), merupakan kategori baik. Hanya ada 8 Responden yang memiliki pengetahuan kurang, atau sebanyak 52 dari 60 responden memiliki pengetahuan Cukup dan Baik, hal ini menunjukkan bahwa para pekerja sudah mengenal dan memiliki pengetahuan 
khususnya tentang K3 pada proses bongkar muat dengan baik. Selain dari kualitas SDM yang sudah baik, hal ini tidak terlepas dari peran perusahaan khususnya dalam kebijakan K3 yang diterapkan untuk memberikan kepedulian terhadap keselamatan kerjanya.

\section{Unsafe Action}

Unsafe action adalah tindakan tidak aman yang dilakukan pada saat bekerja yang dapat memicu terjadinya kecelakaan kerja, dalam penelitian ini peneliti membagi tingkat unsafe action menjadi 4 kategori, yaitu sangat rendah jika index Unsafe actionnya sebesar $<25 \%$, Rendah jika index unsafe Actionnya sebesar 26-50\%, sedang jika index unsafe actionnya sebesar $51-75 \%$ dan tinggi jika index unsafe action sebesar $>76 \%$. Responden dalam penelitian ini sebanyak 60 responden, 27 responden atau sebesar 45,0\% Tenaga Kerja Bongkar Muat dinyatakan unsafe action berkategori cukup ,dan tidak ada satu pun responden memiliki unsafe action kategori tinggi. Berdasarkan hasil penelitian ini dapat dikatakan bahwa Tenaga Kerja bongkar muat sudah melakukan pekerjaan proses bongkar muat dengan baik, karena tidak ada satu pun dari Tenaga Kerja Bongkar muat memiliki unsafe action kategori Tinggi, hal ini disebabkan baiknya kebijakan K3 yang diterapkan pada perusahaan dan pengawasan dari supervisior TKBM maupun Supervisor Bongkar muat/lapangan yang baik

\section{Hubungan Karakteristik Pekerja dan Unsafe Action}

Tabel 4. Kuat Hubungan Karakteristik Pekerja terhadap Unsafe Actions

\begin{tabular}{lcl}
\hline \multicolumn{1}{c}{ Variabel } & $\begin{array}{c}\text { Koefisien } \\
\text { Korelasi }\end{array}$ & \multicolumn{1}{c}{$\begin{array}{c}\text { Kuat } \\
\text { Hubungan }\end{array}$} \\
\hline Umur & 0,090 & Sangat lemah \\
Masa Kerja & 0,327 & Rendah \\
Pendidikan Terakhir & 0,324 & Rendah \\
Pengetahuan & 0,417 & Cukup kuat \\
\hline
\end{tabular}

\section{Hubungan Umur dengan Unsafe Action}

Terdapat alasan mengapa usia dihubungkan dengan kinerja seseorang, yaitu ,Kinerja yang semakin menurun dengan meningkatnya usia hal ini dikarenakan keterampilan-keterampilan fisik seperti kecepatan, kelenturan, kekuatan, dan koordinasi akan menurun dengan bertambahnya umur (Suma'mur, 2009). Hasil dalam penelitian ini, didapatkan bahwa unsafe action pada pekerja justru lebih banyak dilakukan oleh pekerja usia tua yaitu sebesar $11(18,3 \%)$ tindakan tidak aman, hal ini menunjukkan bahwa keterampilan fisik dan kinerja yang semakin menurun dengan bertambahnya umur. Selain itu, pada pekerja tua telah terjadi penurunan keadaan fisik, intelektual, ingatan jangka pendek, dan kecepatan pengambilan keputusan sehingga pekerja tua akan cenderung melakukan pekerjaan yang monoton yang dapat mengakibatkan semakin kecilnya potensi orang tersebut untuk melakukan perbuatan berbahaya kategori tinggi, sebaliknya mereka akan lebih sering melakukan tindakantindakan hampir berbahaya atau unsafe action kategori sedang (Muchlas, 2008). Berdasarkan perhitungan statistik nilai koefisien korelasi antara umur dan unsafe action adalah 0,090 artinya umur dan unsafe action memiliki kuat hubungan sangat lemah. Hal ini sejalan dengan penelitian yang dilakukan oleh Listyandini (2013) bahwa tidak ada hubungan yang bermakna antara perilaku tidak aman dengan usia.

Hasil penelitian berbeda dengan teori yang menyatakan bahwa pekerja dengan usia lebih muda secara psikologi akan cenderung lebih cepat, agresif, tergesa-gesa dan terburu-buru dalam bekerja sehingga cenderung melakukan unsafe action yang berpotensi mengurangi kinerja bahkan mengakibatkan kecelakaan kerja. Hal tersebut dapat terjadi karena Usia dapat mempengaruhi unsafe action, namun perlu ditekankan bahwa usia termasuk karakteristik yang dimiliki seseorang yang dapat mempengaruhi unsafe action meskipun masih ada beberapa faktor lain yang mendominasi timbulnya unsafe action tersebut.

\section{Hubungan Masa Kerja dengan Unsafe Action}

Suma'mur (2009) menyatakan bahwa pengalaman seseorang untuk mengenal bahaya di tempat kerja akan semakin membaik seiring dengan bertambahnya usia dan masa kerja, sehingga pada pekerja lama akan lebih mengenal titik-titik bahaya pada tempat kerja mereka yang pada akhirnya dapat meminimalkan terjadinya kesalahan (error) yang dapat mengakibatkan kecelakaan. Berdasarkan sebuah penelitian oleh Sholehudin (2013) yang menyatakan bahwa semakin bertambahnya masa kerja maka akan semakin rendah persentase pekerja tersebut untuk melakukan unsafe action.

Berdasarkan perhitungan statistik nilai koefisien korelasi antara masa kerja dan unsafe action adalah 0,327 artinya masa kerja dan unsafe action memiliki kuat hubungan rendah, Hasil ini 
didukung dengan adanya penelitian lain serupa yang menyatakan bahwa tidak ada hubungan yang bermakna antara perilaku tidak aman dengan masa kerja (Listyandini, 2013).

Sebuah penelitian oleh Sholehudin (2013) yang menyatakan bahwa semakin bertambahnya masa kerja maka akan semakin rendah persentase pekerja tersebut untuk melakukan unsafe action, namun hasil dalam penelitian ini menunjukkan hubungan yang rendah antara masa kerja dan unsafe action. Hal tersebut dapat terjadi karena pada kenyataannya kondisi di lapangan yang berbeda, para Tenaga kerja bongkar muat yang merasa bahwa pekerjaan bongkar muat memiliki risiko kerja yang tinggi cenderung memilih keluar dari perusahaan untuk berhenti atau mencari pekerjaan yang lebih aman, mengingat profesi sebagai TKBM tidak memiliki jenjang karir, sehingga keluar masuk pekerja cukup tinggi. Demikian juga orang-orang yang masih menetap di perusahaan sehingga memiliki pengalaman kerja yang lebih lama, itu karena mereka memang tidak memiliki alasan untuk keluar dari perusahaan kecuali karena usia atau mengalami kecelakaan kerja (Winarsunu, 2008). Sehingga masa kerja atau pengalaman kerja yang lama bukan merupakan faktor penentu bahwa pekerja tersebut dapat berperilaku aman selama bekerja.

\section{Hubungan Pendidikan dengan Unsafe Action}

Peristiwa kecelakaan kerja memiliki berbagai penyebab, Salah satu penyebabnya adalah perbuatan tidak aman, seperti perbuatan tidak aman yang disebabkan karena kurangnya pengetahuan dan keterampilan dan tindakan yang tidak aman. Pendidikan seseorang penting dan harus diperhatikan untuk meningkatkan kesadaran akan arti pentingnya kesehatan dan keselamatan kerja (Permana, 2014).

Berdasarkan perhitungan statistik nilai koefisien korelasi antara pendidikan terakhir dan unsafe action adalah 0,324 artinya pendidikan terakhir dan unsafe action memiliki kuat hubungan rendah. Hal ini tidak sejalan dengan teori yang mengatakan bahwa pendidikan seseorang tenaga kerja mempengaruhi cara berpikirnya dalam menghadapi pekerjaanya, termasuk cara pencegahan kecelakaan maupun menghindari kecelakaan kerja saat melakukan pekerjaanya (Permana, 2014) .Hal tersebut terjadi karena kenyataan di lapangan di mana para Tenaga Kerja Bongkar muat yang sebagian besar memiliki tingkat pendidikan terakhir yang beragam memiliki keterampilan dalam proses bongkar muat yang berbeda pula, mengingat proses bongkar muat adalah jenis pekerjaan yang lebih membutuhkan keterampilan, fisik dan skill dibandingkan dengan kemampuan pendidikan formal. Sehingga faktor pendidikan belum tentu menentukan tindakan tidak aman yang dilakukan oleh pekerja.

\section{Hubungan Pengetahuan dengan Unsafe Action}

Pengetahuan yang dimiliki seseorang merupakan faktor yang sangat berperan dalam menginterpretasikan stimulus yang kita peroleh. Pengetahuan adalah hasil penginderaan manusia atau hasil tahu seseorang terhadap objek melalui indera yang dimilikinya melalui mata, hidung, telinga, dan sebagainya. Pekerja mampu mengidentifikasi adanya bahaya melalui penginderaan tersebut. Oleh karena itu, pekerja dengan pengetahuan yang baik dapat mencegah terjadinya kecelakaan kerja baik pada dirinya maupun orang lain (Notoatmodjo, 2007).

Berdasarkan perhitungan statistik nilai koefisien korelasi antara pengetahuan dan unsafe action adalah 0,417 artinya pengetahuan dan unsafe action memiliki kuat hubungan cukup kuat. Hal ini sejalan dengan penelitian, di mana hasil penelitian menunjukkan bahwa responden yang memiliki pengetahuan baik memiliki unsafe action dengan kategori sangat rendah yaitu sebesar $20 \%$.

\section{SIMPULAN}

Penelitian pada Tenaga Kerja Bongkar Muat di PT. Terminal Petikemas Surabaya dapat disimpulkan bahwa Sebagian besar responden berada pada ketegori umur dewasa dan lansia dan sebagian besar memiliki tingkat pendidikan terakhir SMA, selain itu Sebagian besar responden memiliki masa kerja di atas 7 tahun dan memiliki pengetahuan yang baik.

Hasil observasi unsafe action menunjukkan bahwa tidak ada satu pun pekerja yang memiliki unsafe action dengan kategori tinggi, karena semua Tenaga kerja rata-rata memiliki unsafe action pada kategori sangat rendah sampai sedang.

Dari uji kuat hubungan antara karakteristik pekerja dengan unsafe action terdapat variabel yang memiliki hubungan cukup kuat dengan unsafe action kerja yaitu pengetahuan.

Berdasarkan Penelitian yang sudah dilakukan, maka saran yang dapat diberikan kepada pihak manajemen di bagian proses bongkar muat di PT. TPS dalam upaya menurunkan Unsafe action untuk mengurangi potensi terjadinya kecelakaan kerja Perusahaan bisa memberikan penyegaran melalui pelatihan maupun pengarahan yang terjadwal untuk 
meningkatkan pengetahuan $\mathrm{K} 3$ di tempat kerja, selain itu perusahaan juga disarankan memberikan pelatihan mengenai posisi kerja yang benar sesuai prinsip ergonomi karena dari hasil observasi sebagian besar Tenaga Kerja Bongkar Muat melakukan unsafe action yang berhubungan pada posisi kerja yang salah.

Selain pengendalian dengan upaya peningkatan dari sisi Tenaga kerja, penekanan tindakan tidak aman dapat dilakukan dengan upaya peningkatan kualitas pengawasan dari Supervisor lapangan pada saat bongkar muat dan lebih tegas kepada Tenaga Kerja Bongkar Muat yang melakukan unsafe action.

\section{DAFTAR PUSTAKA}

Cheyne, Alister, Jose M. Tomas and Sue Cox. 2002. The Effects of Organizational and individual factors on Occupational accidents. Journal of Occupational and Organizational Psychology .volume 75, issue 4, pages 473-488.

Gatiputri, Rona. 2011. Gambaran Tindakan Bahaya dan Kondisi Bahaya terhadap Risiko Terjadinya Kecelakaan Kerja di Devisi Kapal Niaga PT. PAL Indonesia Surabaya. Jurnal. Surabaya, ADLN Perpustakaan Universitas Airlangga.

ILO. 2013. Health and Safety in Work Place for Productivity. Geneva: International Labour Office.

Listiyandini, Rahma. 2013. Analisis Faktor yang Berhubungan dengan Perilaku tidak Aman pada Pekerja Kontraktor di PT. X . Jurnal. Surabaya, ADLN Perpustakaan Universitas Airlangga.

Muchlas. 2008. Manajemen Sumber Daya Manusia. Jakarta. Bumi Aksara.

Notoatmodjo, S. 2007. Pengantar Pendidikan dan Ilmu Perilaku Kesehatan. Yogyakarta: Andi Offset.
Permana, A. Surya. 2014. Hubungan personal factor dengan unsafe action proses pemasangan pipa baja oleh PT. Putra Negara Surabaya. Jurnal. Surabaya, ADLN Perpustakaan Universitas Airlangga.

Pratama, A.K. 2015. Hubungan antara karakteristik pekerja dan tipe kepribadian dengan unsafe action pada Tenaga Kerja Bongkar Muat di PT. Terminal Petikemas Surabaya . Skripsi, Surabaya, Universitas Airlangga

Ramli, Soehatman. 2010. Pedoman Praktis Manajemen Risiko dalam PrespektifK3. Jakarta: Dian Rakyat

Riduwan. 2013. Metode dan Teknik Menyusun Tesis. Bandung: Alfabeta

Rosyid Daniel M. dan Gusriana H, Rima. 2011. Studi Peran Keandalan Manusia dalam Tubrukan Kapal (Studi Kasus Pelabuhan Tanjung Perak Surabaya.

Santoso, Gempur. 2004. Ergonomi manusia, peralatan, dan lingkungan. Sidoarjo. Prestasi pustaka publisher.

Septiana, Dwi. 2014. Hubungan karakteristik pekerja dengan unsafe action di PT. Pupuk Kalimantan Timur. Jurnal. Surabaya, ADLN Perpustakaan Universitas Airlangga.

Silalahi Bennet N.B dan Rumondang B. Silalahi. 1995. Manajemen Keselamatan dan Kesehatan Kerja, PT. Pustaka Binaman Pressindo, Jakarta

Sholehudin, Moch. 2013. Hubungan Personal factor dengan unsafe action di unit X- PT. Baja X, Jurnal. Surabaya, ADLN Perpustakaan Universitas Airlangga.

Suma'mur, P.K. 2009. Higiene Perusahaan dan Kesehatan Kerja. Jakarta: PT. Toko Gunung Agung. Cetakan XII

Sugian, Syahu O. 2006. Kamus Manajemen (Mutu), Jakarta: PT Gramedia Pustaka Utama,

Winarsunu Tulus. 2008. Psikologi Keselamatan Kerja, Malang. Penerbit Universitas Muhammadiyah Malang. 